\title{
Е.В. Чайчина
}

Новосибирский государственный университет

\section{Производные имена существительные, образованные продуктивными аффиксами по модели $\mathbf{T n}=u b$, Tn $=л ы к$, в современном алтайском языке}

Аннотация: В статье рассматривается проблема образования имен существительных в алтайском языке. В центре внимания - продуктивные аффиксы $=4 b l$, =лык с помощью которых образуются имена существительные со значением профессии, деятельности так же абстрактных и обобщенных понятий.

The article deals with the problem of noun formation in the Altai language. The main focus is on the productive affixes $=c h y,=l y k$ which form nouns with the meaning of occupation, work and abstract and generalized notions as well.

Ключевые слова: аффикс, имя существительное, словообразование, модель

Affix, noun, word-formation, model.

УДК: 81'44.

Контактная информация: Новосибирск, ул. Пирогова, 2. НГУ, гуманитарный факультет. Тел. (383) 3634155. E-mail: ozok@mail.ru.

Одним из способов словообразования является словообразовательная аффиксация, имеющая широкое распространение в тюркских языках.

В данной статье рассматриваются производные имена существительные, образованные продуктивными аффиксами по модели $\mathrm{Tn}=4 b l, \mathrm{Tn}=л ь к$.

Модель - понимается как устойчивая структура («образец/ схема») с определенной собственной семантикой [Доржиева, 2007, с. 14].

$\mathbf{T n}=\mathbf{4 ы}$

Схема, структурную схему $\mathrm{Tn}=4 ы$ в алтайском языке имеют 9 моделей.

1. X - 'биофакт' $\rightarrow$ 'лицо, добывающее $\mathrm{X}$ ': тӧгӧт 'деготь' $\rightarrow$ тӧгӧтчи 'дягтерник', кузук 'орех' $\rightarrow$ кузукчы 'человек, собирающий и продающий орехи', калбачы 'человек, собирающий и продающий калбу' $\rightarrow$ калба 'калба', саныт 'сера' $\rightarrow$ caнытчы 'человек, собирающий и продающий серу': Кузукчылар боочыны ажа бердилер (БУ Т, 263) - Люди, собирающие орех, перевалили перевал.

Је, обедтин кийнинде бир де кузукчы јанбады (ЛК, 179) - Но, после обеда не вернулся ни один из сборщиков орехов (человек, который пошел собирать орехи).

Санылтчылар јаан от салдылар (АА Ӧ, 372) - Сборщики, собирающие серу, развели большой огонь.

2. X - 'животное' $\rightarrow$ 'лицо, выращивающее, заботящееся или занимающееся охотой на X': кой 'овца' $\rightarrow$ койчы 'чабан', јылкы 'лошадь' $\rightarrow$ jылкычы 'табунщик', эчки 'коза' $\rightarrow$ эчкичи 'тот, кто пасет коз', сарлькк 'як' $\rightarrow$ сарлыкичы 'тот, кто пасет яков', тийин 'белка' $\rightarrow$ тийинчи 'тот, кто охотится на белок', тӱлкё 'лиса' $\rightarrow$ тӱлкёчи 'охотник на лис', шонкор 'сокол' $\rightarrow$ шонкорчы 'тот, кто охотится на сокола'. 
Примеры: Aды - Керик. Сӧӧги - ара. Талдунын ла бойында чьлккан-ӧскӧн, эмди колхозтын эн артык койчblзыl - (ТШ Ы, 237) - Имя - Керик. Родом из - ара. В Талде родился и вырос, теперь лучший чабан колхоза.

Эмди јылкычыллар Ӧмӧлик ле Јаркын (СМ А, 345) - Теперь табунщики Омолик и Дьаркын.

Кьзыл-Ташка једип келерде, јылккычынын ийди де ӱрбеди, бойы да кӧрӥнбеди (ЭТ К, 33) - Когда дошел до Кызыл-Таша, собака то табунщика не залаяла и самого то не было видно.

Баштапкы карга тийинчилер суйнет (ЭЯ А, 75) - Охотники на белок радуются первому снегу.

3. X - 'артефакт' $\rightarrow$ 'лицо, профессионально создающее X': јурук 'картина' $\rightarrow$ јурукчьl 'художник': Јаан кӧзнӧктӧрлӥ кыптын стенезинде кандый да јурукчынын јуругын илип салтыр (ТШ Ы, 174) - В комнате с большими окнами на стене повесили картину какого-то художника.

4. X - 'орудия действия, средство прередвижения' $\rightarrow$ 'лицо, работающее с орудием труда, управляющее машиной, механизмом X': чалгы 'коса' $\rightarrow$ чалгычы 'косарь', маска 'молоток' $\rightarrow$ маскачы 'кузнец', паром $\rightarrow$ паромчы 'паромщик', салда 'плуг, соха' $\rightarrow$ салдачьl 'пахарь', мотор $\rightarrow$ моторчь 'моторист', кеме 'лодка' $\rightarrow$ кемечи 'лодочник', кайык 'весло' $\rightarrow$ кайыкчы 'гребец', чана 'лыжи' $\rightarrow$ чаначы 'лыжник'.

Примеры: Кемечинин болужыла бис ол јаратта болдыс (ЈК У, 171) - С помощью лодочника мы оказались на том берегу.

Чалгычыларыдн алдында јаан јалан јатты (ЛК А, 79) - Перед косарями лежало большое поле.

Ладимир чындап та јакшы чаначы болгон (ЛК, 272) - И в правду, Ладимир был хорошим лыжником.

Аттар башкарып турган уул салдачыга болужып та ийер эди, је нении эдерин бойь да аайлабайт (ЭТ К, 47) - Парень, который управляет лошадьми, мог и помочь пахарю, да только сам не понимает.

5. X - 'объект природы' $\rightarrow$ 'лицо, профессионально связанное с X': талай 'море' $\rightarrow$ талайчь 'моряк': Јаан уульлм талайчьы (ЭЯ А, 88) - Мой старший сын моряк.

6. X - 'профессиональное действие' $\rightarrow$ 'лицо, занимающееся X профессионально': јаргы 'суд’ $\rightarrow$ јаргычы 'судья', шылу 'допрос' $\rightarrow$ шылууиы 'исследователь', кӥреш 'борьба' $\rightarrow$ кӱрешчи 'борец’: Кебисте кӥрешчи уулдар јуульишты (АЧ № 79 2002) - На арене собрались борцы.

Шылучь ижин баштап. ийди (ЛК А, 63) - Следователь начал свою работу.

Јаргычы канайда јаргылаар, ондый ла болор (АК, 137) - Как присудит судья, так и будет.

В «Русско-алтайско-английский словаре общественно-политических и социально-экономических терминов» под редакцией Н.Н. Тыдыковой включено 10 неологизмов с аффиксом =чbl. Например: керечи 'свидетель' от кере 'свидетельство': Бир де керечи јок болордо јаргыны токтодып салды (инф.) - Из-за отсутствия свидетелей суд был отложен.

колтыкчы 'приспешник' от колтык 'подмышка'; курмакчы 'фальсификатор' курмак 'фальш'; астамчы 'рвач’ астам 'выгода'; аргачы 'комерсант' арга 'способ'.

Интересно, что последнее слово в республиканской газете «Алтайдын Чолмоны» употребляется в значении 'спонсор'. Среди опрошенных информантов 50\% употребляет слово аргачы в значение 'спонсор': Ууртта кандый бир байрам болзо, кичинек те болзо, аргачылар болужын јетирет (инф.) - Если в деревне проходит какой-нибудь праздник, то спонсоры хоть помаленьку, но помогают. С этим значением слово уже вошло в лексику алтайского языка, и официально 
принято Терминологической комиссией по алтайскому языку при Правительстве Республики Алтай.

7. X - 'национальный музыкальный инструмент' $\rightarrow$ 'лицо, играющее на X профессионально': шоор 'дудка' $\rightarrow$ шоорчы 'игрок на дудке', топшуур 'двухструнный национальный инструмент' $\rightarrow$ топшуурчьл 'игрок на топшууре', комус 'национальный губной инструмент' $\rightarrow$ комысчьл 'игрок на комусе': Koмyсчьы кыс кӧӧрӧчилерге удура чыгып келди (СМ А, 64) - Девушка, играющая на комусе, вышла навстречу зрителям.

Бир катап ӱч нӧкӧр андап барган, бирӱзи - иоорчьы, экинчизи ӱчинчизи кайчьл болгон (АК, 62) - Однажды три товарища пошли на охоту, один игрок на дудке, второй - игрок на топшуре, а третий был исполнителем горлового пения.

8. Х - 'произведение устного народного творчества' $\rightarrow$ 'лицо, исполняющее $\mathrm{X}$ ': кай ‘горловое пение' $\rightarrow$ кайчы 'исполнитель горлового пения', чӧрчӧк 'сказка' $\rightarrow$ чӧрчӧкчи 'сказочник'.

Курмач-Байголдо Герасим Кандараков деп коркышту јаан кайчы болгон $($ АК, 288) - Герасим Кандараков в Курмач-Байголе был известным исполнителем горлового пения.

Алтайда ады-јарлу чёрчӧкчи Танытпас Акулованын бичиги чыккан (инф.) Вышла книга известного на Алтае сказочника Танытпас Акуловой.

9. X - 'имена существительные, называющие какое-либо эмоции, социальном действие $\rightarrow$ 'лицо, характеризующееся отрицательным качеством $\mathrm{X}$ ': тӧгён 'обман' $\rightarrow$ тӧгӱнчи 'обманщик', коп 'сплетня' $\rightarrow$ копчы 'сплетник', тарма 'магия, колдовство' $\rightarrow$ тармачы 'колдун, гадатель', ууры 'воровство' $\rightarrow$ уурчы 'вор': Онын копчызын билбедим (ЭП А, 69) - Я не знала, что она такая сплетница.

Айсулу ондый тӧгёнчи сӧстӧрине бӥтпе (БУ Т, 232) - Айсулу такая обманщица, не верь ее словам.

Сен уурчыга не болужып турун? (К J, 61) - Почему ты помогаешь вору?

Керек уурчынын кӱуниле болуп калды (ЭТ К, 34) - Дело произошло по желанию вора.

- Бу јоон эмеген тармачы да болзо, кем билер оны? ... - деп, ол сананып туратан (ЛК, 310) - Даже если эта женщина крупного телосложения - колдунья, кто ее знает? ... - так он думает про нее.

\section{$\mathbf{T n}=л ы к ~$}

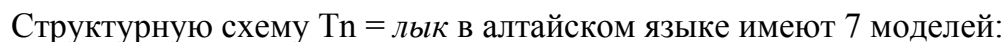

1. X - 'название частей суток' $\rightarrow$ 'имена существительные обозначающие

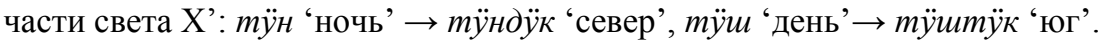

Кеткин куштар јас келгенде, тӥштӥктен учып келгилейт (инф) - Весной с юга прилетают перелетные птицы. Т̈̈штӥктен келген стороительдердин табыштары угулып туру (инф.) - Слышны голоса строителей, приехавших с юга.

Ыраак тӥндӥктен учуп брааткан турналардын кыйгызы кажы ла кижинин јӱрегине ачу-ачу томульп турар болды (ЭТ К, 78) - Крики журавлей, летевших с далекого севера, будут печалью охватывать сердце каждого человека.

2. X - природный объект $\rightarrow$ 'имена существительные, выражающие определенный отрезок времени': ай 'месяц' $\rightarrow$ айльк 'месячник':

Республиканын кажы ла аймактарында карганактардын кӱндерине учурлалган айльљктар ӧд̈̈n јат (АЧ №99 1999) - В каждом районе республики идут месячники, посвященные к дню пожилого человека.

3. X - отрезок времени $\rightarrow$ 'предмет используемый, в учебной деятельности':

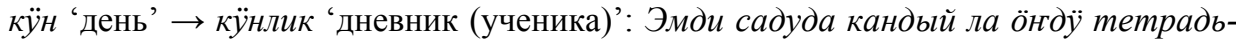
map, кёнликтер бар (инф.) - Теперь в продаже есть всякие цветные тетради и дневники.

4. X ‘название людей' $\rightarrow$ 'собрание людей, единомышленников X': кижи 
‘человек' $\rightarrow$ кижлик 'человечество', најыл 'друг, товарищ' $\rightarrow$ најылык 'товарищество'. Кижиликтин ойгорлоры кижи деп неме ай-казыр кылыгын таштап, керсё ле јакшы кё̈̈ндё улус болуп ӧссин деп кӧп бичиктер арттыртыр (JM J, 10) Мудрецы мира (букв. человечества) после себя оставили много книг, чтобы люди отбросив свой коварный нрав, росли с хорошим, умным старанием.

Кижилик кандьій једимдерге јетпеди. Тоолоп то болбозор (ЭА, 67) - Человечество каких только успехов не достигло. И сосчитать-то невозможно.

5. X 'термин родства' $\rightarrow$ 'положение, состояние, определяемое семантикой $X^{\prime}$ :

эне 'мать' $\rightarrow$ энелик 'материнство': Эне болгон кийнинде энелик деп сӧстин учурын, байла, ондорын [JM J, 56] - Став матерью, наверное, узнаешь значение слова 'материнство'.

6. X - 'предметы быта' $\rightarrow$ 'название бытовых предметов, связанных с X по сходству форме':

кын 'ножны' $\rightarrow$ кындак 'ложе ружья'.

ийне 'иголка' $\rightarrow$ ийнелик 'вязальные спицы': Јаанам тӥунерге сӥур, онын учун айльнда кандый ла ийнеликтер бар (инф.) - Бабушка любит вязать, поэтому у нее дома много спиц разных размеров.

7. X - 'профессия или должность' $\rightarrow$ 'название учреждений, где протекает деятельность $\mathrm{X}$ ': эмчи 'врач, доктор' $\rightarrow$ эмчилик 'больница', элчи 'посол' $\rightarrow$ элчилик 'посольство’: Бешпелтир јуртта јыны эмчилик ачылды (АЧ № 122 2003) - В селе Бешпельтир открылась новая больница.

Также этот аффикс может присоединяться к основам имен прилагательных в единичных случаях к числительным. Так, от имен прилагательных: јебрентик ‘древность' (јебрен 'древний’), мӧнкӥлик 'вечность' (мӧнкё ‘вечный’), јакшылык 'доброта' (јакщы 'хороший’), байлькк ‘богатство' (бай 'богатый’), чындык 'справедливость' (чыл 'правда, истина'); от имен числительных образовано небольшое количество слов: бирлик 'единство' (бир ‘один'), онкӱндёк ‘десятидневка' (он кён 'десять дней').

Бронтой Бедюров, оос поэзиядагы айдылган кйун-санааларды бӥгӥнги ӧйдин сурактарыла колбоп, јаны учурлу ла, эмдиги ле анчада ла эртенги уйеге сӥрекей керектӥ сурактар кӧдйрип јат: ар-бӥткен ле кижи, эмдиги экпиндё јаныртулар ла эне-адаларыбыстын эрјине энчилери, кижи ле кижилик, јуу-чак ла амыр-энчё, јӱримм ле ӧлйм, јакшылык ла јамандык јаантайын удурлажа тартышканы ла онон до ӧскӧлӧри (ББ А, 4) - Бронтой Бедюров, связывая мысли, которые высказаны в устной народной поэзии, с современными с новыми значениями поднимает актуальные вопросы для нового поколения: природа и человек, перестройка и драгоценное наследие родителей, человек и человечество, война и мир, жизнь и смерть, добро и зло в постоянном противоборстве и другие.

Кӧрӥп турзан, кайдаар да учь јок мӧнкӱликке баргылап јаткан ошкош (БУ Т, 33) - Когда смотришь на них, как будто они идут в бесконечную вечность.

Кажы ла иште чындык болор керек (инф.) - Во всякой работе должна быть справедливость.

Из проанализированного материала можно сделать предварительный вывод о том, что в алтайском языке при помощи аффикса $=4 b l$ образуются имена существительные в основном от существительных. Исходными основами производных на =иы служат наименования живых существ, растительности, предметов, орудий, отвлеченных понятий.

Все они, оснащаясь данным аффиксом, называют лицо по роду его занятия и деятельности. Род занятия и деятельности лица заложен в значении исходных основ, который переходит в значение деятеля как определяющий его признак.

Производные слова, образованные от аффикса =лык в алтайском языке обозначают вещи и приспособления, а также абстрактные и обобщенные понятия. 
Иногда счетные существительные полностью теряют количественное значение и приобретают отвлеченное значение: бирлик ‘единство' (бир ‘один’).

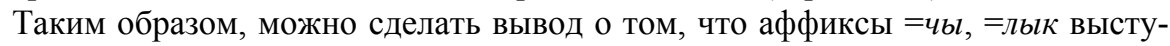
пают в качестве одного из наиболее продуктивных словообразующих аффиксов в современном алтайском языке.

\section{Литература}

Доржиева Д.С. Модели простого предложения с именным сказуемым в бурятском языке. Улан-Удэ, 2007.

Русско-алтайско-английский словарь общественно-политических и социально-экономических терминов. Горно-Алтайск, 2004.

\section{Условные сокращения}

АА Ӧ -Адаров А. Ӧлӱмнин чанкыр кужы. Горно-Алтайск, 1993.

АК - Алтай кеп-куучындар. Горно-Алтайск, 1994.

АЛ - Алтай литература. Горно-Алтайск, 1981.

АЧ - газета Алтайдын Чолмоны.

ББ А - Бедюров Б. Алтайдын алкыштары. Горно-Алтайск, 1985.

БУ Т - Укачин Б. Туулар туулар ла бойы артар. Горно-Алтайск, 1985.

ЈК Ӱ -Каинчин Ј. Ӱстибисте - Ӱч-Сӱмер. Горно-Алтайск, 2003.

Инф - информант Кокпоева Эльмира Маратовна.

ЛК А - Кокышев Л. Алтайдын кыстары. Горно-Алтайск, 1980.

ЛВ - Л.В. Кокышевти кычыралы. Горно-Алтайск, 2005.

СМ А - Манитов С. Аш кылгада. Горно-Алтайск, 1989.

ТШ Ы - Шинжин Т. Ырыс экелген ижемји. Горно-Алтайск, 1986.

ЭП А - Палкин Э. Алан. Горно-Алтайск, 1978.

ЭТ К - Тоюшев Э. Кӱрлер. Горно-Алтайск, 1987.

ЭЯ - Яимов Э. Абыјы тыды. Горно-Алтайск, 2003. 